INTERNATIONAL JOURNAL OF RESEARCHES IN BIOSCIENCES, AGRICULTURE \& TECHNOLOGY (C) VISHWASHANTI MULTIPURPOSE SOCIETY (Global Peace Multipurpose Society) R. No. MH-659/13(N) www.vmsindia.org

\title{
REVIEW ON HEENA PLANT (LAWSONIA INERMIS) AND ITS APPLICATIONS
}

\author{
Swaroopa Rani N. Gupta \\ Dept of Chemistry Brijlal Biyani Science College Amravati, MS, India \\ swargupta@yahoo.com
}

\section{ABSTRACT:}

Henna (Lawsonia inermis) is a flowering plant, 2-6m in height. Henna, Lawsonia inermis, produces a burgundy dye molecule, lawsone. This molecule has an affinity for bonding with protein, and thus has been used to dye skin, hair, fingernails, leather, silk and wool. The dye molecule, lawsone, is primarily concentrated in the leaves. It is well known that plants have been used in traditional herbal medicine for many years. In some parts of the world, plants and herbs are still the prime medicines used in medical treatment. L. inermis is widely grown in various tropical regions in Asia, America and Africa. The main uses of henna are as a cooling agent, astringent, anti-fungal and anti-bacterial herb for the skin and hair. It has also been used as a dye and preservative for hair, skin and fingernails as well as leather and clothes. Its core chemical components are 2-hydroxynapthoquinone (lawsone), mannite, tannic acid, mucilage and gallic acid. Out of these ingredients, the main one is 2-hydroxynapthoquinone (lawsone). Its bioactive feature is thought to be due to its high protein binding capacity.

Henna is known to be dangerous to people with glucose-6-phosphate dehydrogenase deficiency (G6PD deficiency), which is more common in males than females. Infants and children of particular ethnic groups, mainly from the Middle East and North Africa, are especially vulnerable. The United States Food and Drug Administration (FDA) does consider these risks to be adulterants and therefore illegal for use on skin.

This Paper deals with review on study of Henna plant (Lawsonia inermis) and its applications. Paper also deals with FTIR spectra of Heena Green Leaves and Heena Brown Seeds.

FTIR can be routinely used to identify the functional groups and identification/quality control of raw material/finished products. FTIR spectra of Heena Green Leaves and Heena Brown Seeds is obtained at room temperature by using an FTIR Spectrophotometer - Perkin Elmer - Spectrum RX-IFTIR. The spectra is collected in a range from 450 to $4000 \mathrm{~cm}^{-1}$.

Interpretation of FTIR Spectra of Heena Green Leaves and Heena Brown Seeds both shows presence of various functional groups such as Acids - Carboxylic acids $\mathrm{COOH}$; Alcohols - Secondary $\mathrm{CH}-\mathrm{OH}$; Amides $-\mathrm{CO}_{-} \mathrm{NH}_{2}$

Key Words: Lawsonia inermis, Medicinal plant, Antimicrobial activity, Lawsone, Heena Green Leaves, Heena Brown Seeds, FTIR Spectra

\section{INTRODUCTION}

Lawsonia inermis (Henna plant) is a shrub or small tree cultivated in many regions as an ornamental and commercial dye crop [1]. It is mostly found in the tropic, sub-tropic, and semiarid zones of Africa (tropical Savannah and tropical arid zones), south Asia, and north Australia [2]. Henna is a dye prepared from the plant Lawsonia inermis, also known as hina, the henna tree, the mignonette tree, and the Egyptian privet [3], the sole species of the Lawsonia genus. Henna has been used since antiquity to dye skin, hair and fingernails, as well as fabrics including silk, wool and leather. Historically, henna was used in the Arabian Peninsula, Indian Subcontinent, parts of Southeast Asia, Carthage, other parts of North Africa and the Horn of Africa. The name is used in other skin and hair dyes, such as black henna and neutral henna, neither of which is derived from the henna plant [4, 5]. Whole, unbroken henna leaves will not stain the skin. Henna does not stain skin until the lawsone molecules are released from the henna leaf. Dried henna leaves stains the skin if they are mashed into a paste. The lawsone gradually migrates from the henna paste into the outer layer of the skin and bind to the proteins in it, creating a fast stain. Since it is difficult to form intricate patterns from coarse crushed leaves, henna is commonly traded as a powder [6] made by drying, milling and sifting the leaves. The dry powder is mixed with one of a number of liquids, 
including water, lemon juice, or strong tea, and other ingredients, depending on the tradition. Many artists use sugar or molasses in the paste to improve consistency and keep it stuck to the skin better. The henna mix must rest for 1 to 48 hours before use, to release the lawsone from the leaf matter. The timing depends on the crop of henna being used. Essential oils with high levels of monoterpene alcohols, such as tea tree, cajeput, or lavender, will improve skin stain characteristics. Other essential oils, such as eucalyptus and clove, are also useful but are too irritating and should not be used on skin. Henna stains are orange when the paste is first removed, but darkens over the following three days to a deep reddish brown. Soles and palms have the thickest layer of skin and so take up the most lawsone, and take it to the greatest depth, so that hands and feet will have the darkest and most long-lasting stains. Some also believe that steaming or warming the henna pattern will darken the stain, either during the time the paste is still on the skin, or after the paste has been removed. It is debatable whether this adds to the color of the end result as well. After the stain reaches its peak color, it holds for a few days, then gradually wears off by way of exfoliation.
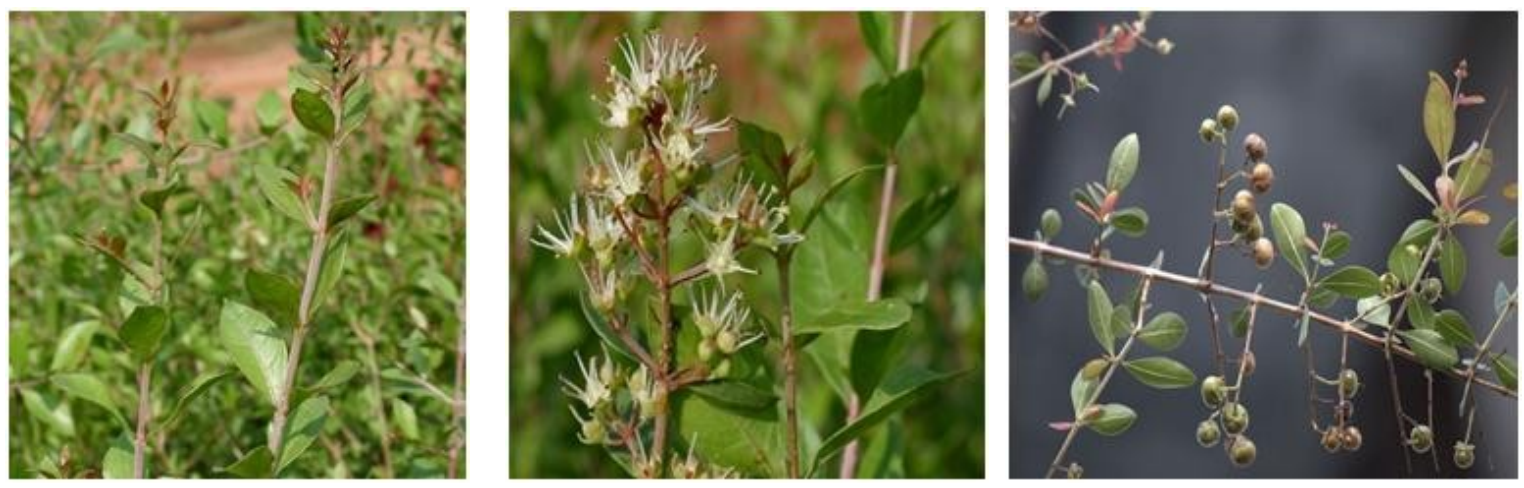

Henna Plant in its different stage

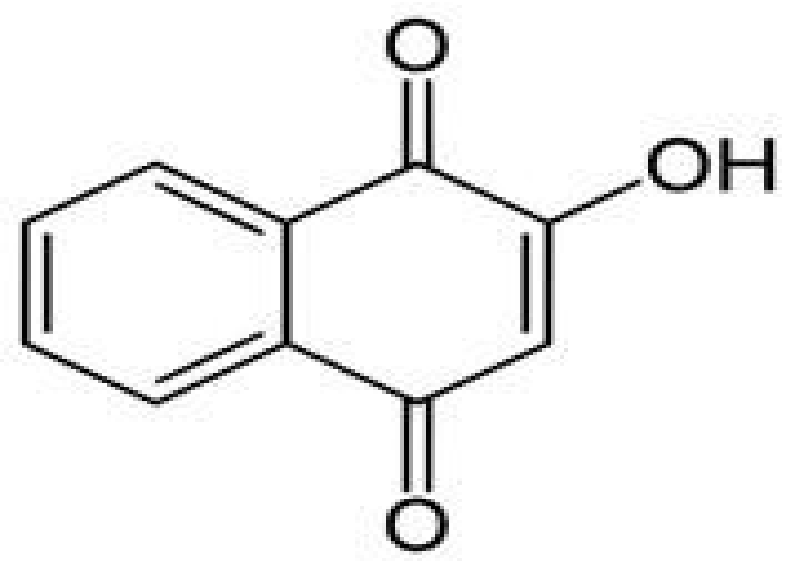

Lawsone $\left(\mathrm{C}_{10} \mathrm{H}_{6} \mathrm{O}_{3}\right)$ (2-Hydroxy-1,4-Naphthoquinone), an active compound in Henna

Henna is known to be dangerous to people with glucose-6-phosphate dehydrogenase deficiency (G6PD deficiency), which is more common in males than females. Infants and children of particular ethnic groups, mainly from the Middle East and North Africa, are especially vulnerable
[7]. The United States Food and Drug Administration (FDA) does consider these risks to be adulterants and therefore illegal for use on skin [8]. Some pastes have been noted to include: silver nitrate, carmine, pyrogallol, disperse orange dye, and chromium [9]. These 
have been found to cause allergic reactions, chronic inflammatory reactions, or late-onset allergic reactions to hairdressing products and textile dyes [10, 11]. An attempt was done to evaluate the hepatoprotective effect of Lawsonia inermis leaves methanolic extract on carbon tetrachloride $\left(\mathrm{CCl}_{4}\right)$-induced hepatotoxicity in rats.[12] Wide range of chemical constituents have been isolated from Henna which includes naphthoquinone derivatives (lawsone which is the chief ingredient and the coloring matter in the leaves), phenolic derivatives, coumarins, xanthones, tannins, flavonoids, aliphatic components, triterpenes, sterols and other chemical constituents such as glucose, gallic acid, amino acids, mannitol, trace elements and minerals [13]. As a medicinal plant, Henna has been used in folk remedy as astringent, hypotensive, sedative, and against a headache, jaundice, and leprosy [14]. Leaves were also used for skin diseases, venereal diseases, smallpox, and spermatorrhea. Powered seeds were effective against dysentery and liver disorders. The bark used in a variety conditions, such as burns, jaundice, spleen enlargement, calculus, leprosy, and skin disorders. Root was considered as a potent medicine for gonorrhea, herpes infection, sore eyes, as an abortifacient, and in the treatment of some nervous disorders [15]. Because, seeds were able to alleviate liver disorders, a question was raised about the protective effects of other plants' parts. Lawsonia inermis has been used in herbal medicine for ages. The antibacterial effects of water, alcoholic and oily extracts of Lawsonia inermis leaves against bacterial cultures isolated from various skin diseases were investigated and compared with Tetracycline, Ampicillin, Gentamicin and Ciprofloxacin antibiotics.[16]

Henna (Lawsonia inermis, syn. L. alba) is a flowering plant, 2-6m in height. It is the sole species in the genus Lawsonia in the family Lythraceae.[17] Henna, Lawsonia inermis, produces a burgundy dye molecule, lawsone.[18] This molecule has an affinity for bonding with protein, and thus has been used to dye skin, hair, fingernails, leather, silk and wool. The dye molecule, lawsone, is primarily concentrated in the leaves. Products sold as "black henna" or "neutral henna" are not made from henna, but may be derived from indigo (in the plant Indigofera tinctoria) or Cassia obovata, and may contain unlisted dyes and chemicals.[17] It is well known that plants have been used in traditional herbal medicine for many years.[19] In some parts of the world, plants and herbs are still the prime medicines used in medical treatment.[20-22] L. inermis is widely grown in various tropical regions in Asia, America and Africa. In Arabic, the word "henna" refers to L. inermis.[21-23] The main uses of henna are as a cooling agent, astringent, antifungal and anti-bacterial herb for the skin and hair. It has also been used as a dye and preservative for hair, skin and fingernails as well as leather and clothes.[24-25] Its core chemical components are 2-hydroxynapthoquinone (lawsone), mannite, tannic acid, mucilage and gallic acid. Out of these ingredients, the main one is 2-hydroxynapthoquinone (lawsone). About $0.5-1.5 \%$ of henna is made of lawsone. Its bioactive feature is thought to be due to its high protein binding capacity.[18-25] The skin has a complex flora. Infections can result when there is a breakdown in the integrity of the skin or when the immune defense is compromised. Common skin infections include cellulitis, erysipelas, impetigo, folliculitis, and furuncles and carbuncles.[26] Many types of bacteria have ability to produce skin infections. Staphylococcus aureus is the most common cause of skin infections. It is frequently found in the nose and skin. About $20 \%$ of the population is long-term carriers of S. aureus.[27] Leaf samples of Lawsonia inermis (Li) were examined for their antimicrobial potential. These results confirmed the antibacterial activity of henna leaves and supported the traditional use of the plant in therapy of bacterial infections and disturbances that occurred at the biochemical level. [28]

A new rapid method for the isolation of lawsone from L. inermis through the calcium ion using the Flash and Disc Counter Current Chromatography (DCC) has been suggested. [29] Study was conducted to investigate antifungal activity of Lawsonia inermis (Henna plant).[30] Plants have been used to treat humans, animals, and plant diseases from time immemorial. Herbal medicines have been known to man for centuries [31]. Henna plant, Lawsonia inermis Linn, is such a plant known for healing attributes and is now the subject of intense scientific study [32]. Lawsonia inermis (Henna) is an ornamental evergreen plant cultivated in the tropics [33]. The 
phytochemical analysis of the plant leaves revealed the presence of anthroquinones as major constituents which are commonly known to posses antimicrobial activity [34]. Ethyl acetate extract of Lawsonia inermis was found to be active against all bacteria tested [35]. Screening of the barks of 30 plant species against Microsporum

gypseum and Trichophyton

mentagrophytes showed that only L. inermis L. extract exhibited absolute toxicity. The extract showed broad fungicidal spectrum when tested against 13 ring worm fungi [36]. The effect of the warm aqueous extract of Lawsonia inermis leaf on Carbon tetrachloride (CC14) induced liver damage in healthy Wister albino rats was studied.[37] Study aimed to review the available literature on some of the ethno-botanical uses of seeds, leaves and roots of Lawsonia inermis plant.[38]

This Paper deals with review on study of Henna plant (Lawsonia inermis) and its applications. Paper also deals with FTIR spectra of Heena Green Leaves and Heena Brown Seeds.

\section{METHODOLOGY}

The Henna leaves and seeds were washed with distilled water; shade-dried at room temperature, then grinded into powder by glass mortar and pestle.

FTIR Spectrophotometer - Perkin Elmer Spectrum RX-IFTIR

FTIR can be routinely used to identify the functional groups and identification/quality control of raw material/finished products. Spectrum RX-I offers fast throughput and rapid access to reliable and dependable IR results. High signal to noise ratio makes FTIR more useful for difficult samples. It has resolution of 1 $\mathrm{cm}^{-1}$ and scan range of $4000 \mathrm{~cm}^{-1}$ to $250 \mathrm{~cm}^{-1}$. In the normal mode around $10 \mathrm{mg}$ sample is required in the form of fine powder. The sample can be analyzed in the form of liquid, solid and thin films also.

FTIR spectra of Heena green leaves and Heena brown seeds is obtained at room temperature by using an FTIR Spectrophotometer - Perkin Elmer - Spectrum RX-IFTIR. The spectra is collected in a range from 450 to $4000 \mathrm{~cm}^{-1}$.

\section{RESULTS AND DISCUSSION}

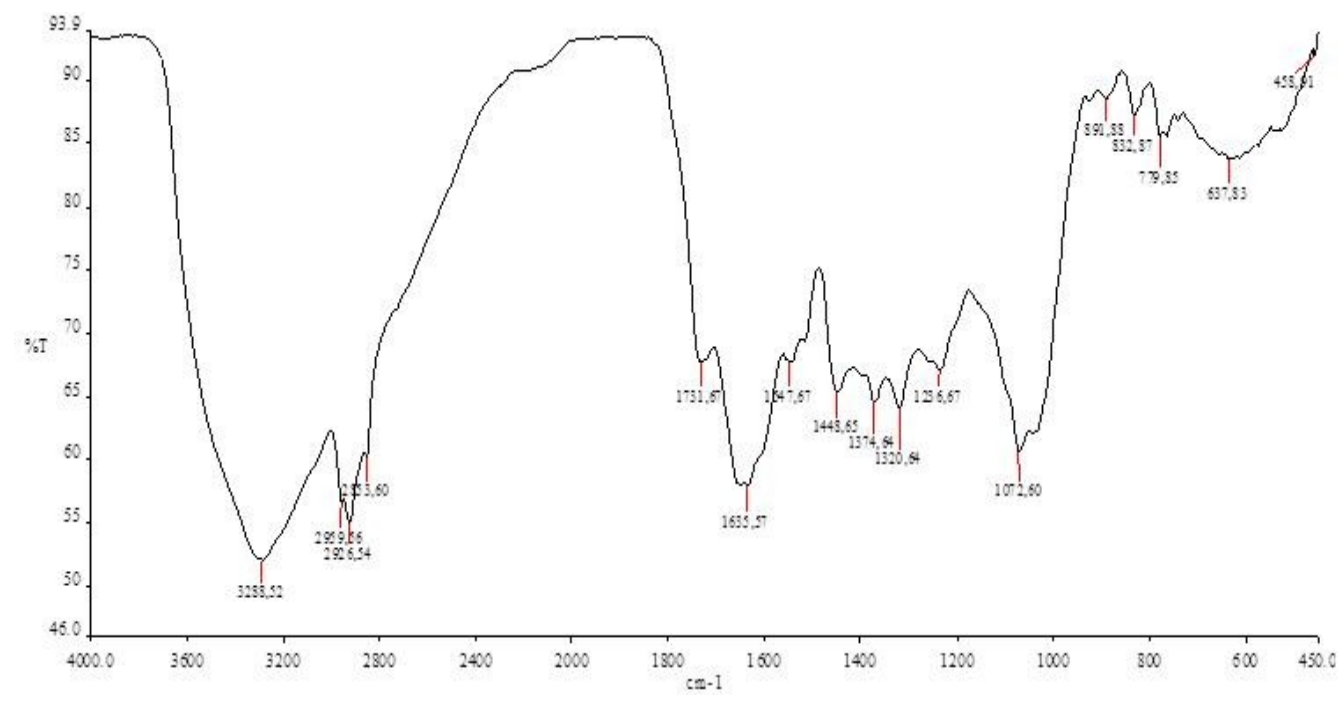

Figure 1. FTIR Spectra of Heena Green Leaves 
Figure 1 shows FTIR Spectra of Heena green leaves. Interpretation of FTIR Spectra of Heena green leaves can be done as follows:

\begin{tabular}{|c|c|c|c|}
\hline S.N. & $\begin{array}{c}\text { Spectral } \\
\text { Region } \\
\text { Wave number } \\
\text { cm }^{-1}\end{array}$ & Bond causing absorption & Pattern and Intensity of Band \\
\hline 1 & 3288.52 & Alcohols - Secondary CH-OH & Broad and Strong Intensity \\
\hline 2 & 2959.56 & - & Broad and Strong Intensity \\
\hline 3 & 2926.54 & - & Broad and Strong Intensity \\
\hline 4 & 2853.60 & - & Broad and Strong Intensity \\
\hline 5 & 1731.67 & Acids - Carboxylic acids $\mathrm{COOH}$ & Broad and Strong Intensity \\
\hline 6 & 1635.57 & Amides - $\mathrm{CO}-\mathrm{NH}_{2}$ & Broad and Strong Intensity \\
\hline 7 & 1547.67 & - & Broad and Strong Intensity \\
\hline 8 & 1448.65 & - & Broad and Strong Intensity \\
\hline 9 & 1374.64 & - & Broad and Strong Intensity \\
\hline 10 & 1320.64 & Acids - Carboxylic acids $\mathrm{COOH}$ & Broad and Strong Intensity \\
\hline 11 & 1236.67 & Acids - Carboxylic acids $\mathrm{COOH}$ & Broad and Strong Intensity \\
\hline 12 & 1072.60 & - & Broad and Strong Intensity \\
\hline 13 & 891.88 & Acids - Carboxylic acids $\mathrm{COOH}$ & Broad and Moderate Intensity \\
\hline 14 & 832.87 & - & Broad and Moderate Intensity \\
\hline 15 & 779.85 & - & Broad and Moderate Intensity \\
\hline 16 & 637.83 & - & Broad and Moderate Intensity \\
\hline 17 & 458.91 & - & Broad and Moderate Intensity \\
\hline
\end{tabular}

Interpretation of FTIR Spectra of Heena green leaves shows presence of various functional groups such as Acids - Carboxylic acids $\mathrm{COOH}$; Alcohols - Secondary $\mathrm{CH}-\mathrm{OH}$; Amides - $\mathrm{CO}-\mathrm{NH}_{2}$

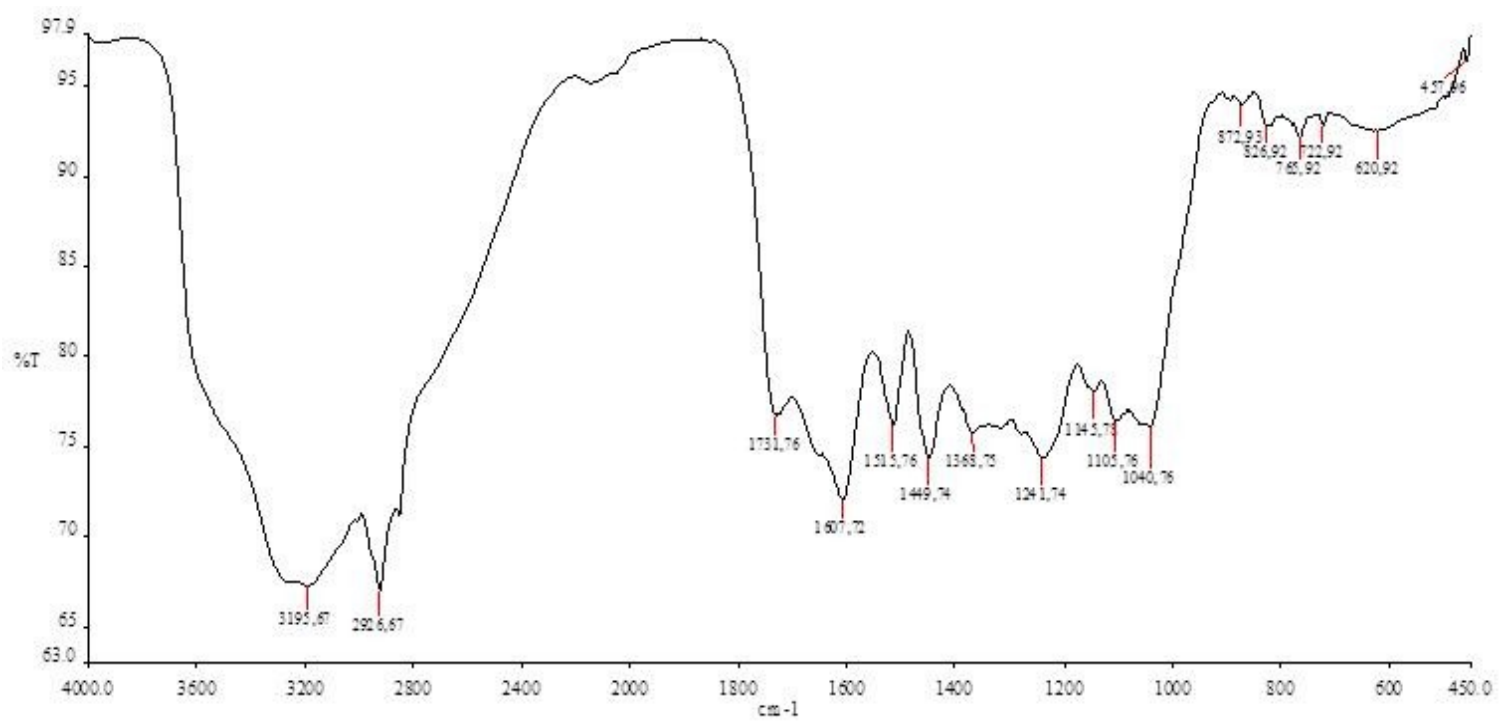

Figure 2. FTIR Spectra of Heena Brown Seeds 
Figure 2 shows FTIR Spectra of Heena Brown Seeds. Interpretation of FTIR Spectra of Heena Brown Seeds can be done as follows:

\begin{tabular}{|c|c|l|l|}
\hline S.N. & $\begin{array}{c}\text { Spectral } \\
\text { Region } \\
\text { Wave number } \\
\mathbf{c m}^{\mathbf{1}}\end{array}$ & \multicolumn{1}{|c|}{ Bond causing absorption } & $\begin{array}{c}\text { Pattern and Intensity of } \\
\text { Band }\end{array}$ \\
\hline 1 & 3295.67 & Alcohols - Secondary CH-OH & Broad and Strong Intensity \\
\hline 2 & 2926.67 & - & Broad and Strong Intensity \\
\hline 3 & 1731.76 & Acids - Carboxylic acids COOH & Broad and Strong Intensity \\
\hline 4 & 1607.72 & Amides -CO-NH 2 & Broad and Strong Intensity \\
\hline 5 & 1515.76 & - & Broad and Strong Intensity \\
\hline 6 & 1449.74 & - & Broad and Strong Intensity \\
\hline 7 & 1368.75 & - & Broad and Strong Intensity \\
\hline 8 & 1241.74 & Acids - Carboxylic acids COOH & Broad and Strong Intensity \\
\hline 9 & 1145.78 & - & Broad and Strong Intensity \\
\hline 10 & 1105.76 & - & Broad and Strong Intensity \\
\hline 11 & 1040.76 & - & Broad and Strong Intensity \\
\hline 12 & 872.93 & Acids - Carboxylic acids COOH & $\begin{array}{l}\text { Broad and Moderate } \\
\text { Intensity }\end{array}$ \\
\hline 13 & 826.92 & - & $\begin{array}{l}\text { Broad and Moderate } \\
\text { Intensity }\end{array}$ \\
\hline 14 & 765.92 & - & $\begin{array}{l}\text { Broad and Moderate } \\
\text { Intensity }\end{array}$ \\
\hline 15 & 722.92 & - & $\begin{array}{l}\text { Broad and Moderate } \\
\text { Intensity }\end{array}$ \\
\hline 16 & 620.92 & - & $\begin{array}{l}\text { Broad and Moderate } \\
\text { Intensity }\end{array}$ \\
\hline 17 & 457.96 & - & $\begin{array}{l}\text { Broad and Moderate } \\
\text { Intensity }\end{array}$ \\
\hline
\end{tabular}

Interpretation of FTIR Spectra of Heena Brown Seeds shows presence of various functional groups such as Acids - Carboxylic acids $\mathrm{COOH}$; Alcohols - Secondary $\mathrm{CH}-\mathrm{OH}$; Amides - $\mathrm{CO}-\mathrm{NH}_{2}$

\section{CONCLUSION}

FTIR can be routinely used to identify the functional groups and identification/quality control of raw material/finished products. Interpretation of FTIR Spectra of Heena Green Leaves and Heena Brown Seeds both shows presence of various functional groups such as Acids - Carboxylic acids $\mathrm{COOH}$; Alcohols Secondary $\mathrm{CH}-\mathrm{OH}$; Amides - $\mathrm{CO}-\mathrm{NH}_{2}$

\section{REFERENCES}

1. Muthumani P, Meera R, Sundaraganapathy Devi P, Mohamed Sheik Arabath S, Cholarja K. Biological evaluation of dried fruits of Lawsonia inermis. J Pharm Biomed Sci. 2010;1:1-5.

2. Donkor Sarkodie C, Quainoo AK, Gustav M. Propagation of Henna (Lawsonia inermis) cuttings using nathelene acetic acid, indole- 3-butyric acid and wood ash. JPBAS. 2013;1:115-23.

3. Jump up^ Bailey, L.H.; Bailey, E.Z. (1976). Hortus Third: A concise dictionary of plants cultivated in the United States and Canada. New York: Macmillan. ISBN 9780025054707 .

4. Jump up^ Cartwright-Jones, Catherine (2004). "Cassia Obovata". Henna for Hair. Retrieved 5 May 2013.

5. Jump up^ Dennis, Brady $(26$ March 2013). "FDA: Beware of "black henna" tattoos". The Style Blog. The Washington Post. Retrieved 5 May 2013.

6. Jump up^ "Henna Powder of Prem Dulhan". Lia. Retrieved December 23, 2015.

7. Jump up^ "Henna and Glucose-6-phosphate dehydrogenase deficiency". The Henna Page. 
8. Jump up to: $\underline{\mathrm{b}}$ "Temporary Tattoos \& Henna/Mehndi". Food and Drug Administration.

9. Jump up to: $\underline{\text { b }}$ Kang IJ, Lee MH (July 2006). "Quantification of para-phenylenediamine and heavy metals in henna dye". Contact Dermatitis. 55 (1):26-

9. PMID 16842550.doi:10.1111/j.01051873.2006.00845.x.

10. Jump up^ Dron P, Lafourcade MP, Leprince $\mathrm{F}$, et al. (June 2007). "Allergies associated with body piercing and tattoos: a report of the Allergy Vigilance Network".European Annals of Allergy and Clinical Immunology. 39 (6): 18992.PMID 17713170.

11. Jump up^ Raupp P, Hassan JA, Varughese M, Kristiansson B (November 2001). "Henna causes life threatening haemolysis in glucose-6-phosphate dehydrogenase deficiency". Archives of Disease in Childhood. 85 (5): 411-2.

12. Musab Awad Mohamed, Imad Mohamed Taj Eldin, Abd-Elwahab Hassan Mohammed, and Hozeifa Mohamed Hassan, Effects of Lawsonia inermis L. (Henna) leaves' methanolic extract on carbon tetrachloride-induced hepatotoxicity in rats, J Intercult Ethnopharmacol. 2016 Jan-Feb; 5(1): 22-26.

13. Varghese JK, Silvipriya K, Resmi S, Jolly C. Lawsonia Inermis (Henna): A natural dye of various therapeutic uses - A review. Inventi Rapid: Cosmeceuticals. 2010;1:1-5.

14. Abdulmoneim Saadabi M. Evaluation of Lawsonia inermis Linn. (Sudanese Henna) leaf extracts as an antimicrobial agent. Res J Biol Sci. 2007;2:419-23.

15. Chaudhary G, Goyal S, Poonia P. Lawsonia inermis Linnaeus: A phytopharmacological review. Int $\mathrm{J}$ Pharm Sci Drug Res. 2010;2:91-8.

16. Kathem K. Al-Rubiay, Nawres N Jaber, A1Mhaawe $\mathrm{BH}$, and Laith K. Alrubaiy, Antimicrobial Efficacy of Henna Extracts, Oman Med J. 2008 Oct; 23(4): 253-256.

17. Singh M, Jindal SK, Kavia ZD, Jangid BL. Khem Chand. Traditional Methods of Cultivation and Processing of Henna. Henna, Cultivation, Improvement and Trade: 21-14. Jodhpur, India: Central Arid Zone Research Institute, 2005.
18. Harborne SB, Baxter A. Phytochemical Dictionary. A handbook of bioactive compounds from plants. Tylor and Francis. London, 1995.

19. Blanks T, Brown S, Cosgrave B, Woody J, Bentley V, O' Sullivan N, et al. The Body Shop Book of Wellbeing Mind, Body, and Soul. Ebury Press London. 1998 p. 173-192.

20. Natarajan V, Venugopal PV, Menon T. Effect of Azadirachta indica (neem) on the growth pattern of dermatophytes. Indian $\mathrm{J}$ Med Microbiol 2003. Apr-Jun;21(2):98101 [PubMed]

21. Hemem SS. Activity of some plant extracts against common pathogens in bacterial skin infection: thesis MSc, College of Education, Basra University, Iraq, 2002.

22. Muhammad HS, Muhammad S. The use of Lawsonia inermis linn. (henna) in the management of burn wound infections. Afr J Biotechnol 2005;4:934-937

23. Habbal OA, Al-Jabri AA, El-Hag AH, AlMahrooqi ZH, Al-Hashmi NA. In-vitro antimicrobial activity of Lawsonia inermis Linn (henna). A pilot study on the Omani henna. Saudi Med J 2005. Jan;26(1):6972 [PubMed]

24. Singh A, Singh DK. Molluscicidal activity of Lawsonia inermis and its binary and tertiary combinations with other plant derived molluscicides. Indian J Exp Biol 2001. Mar;39(3):263-268 [PubMed]

25. Kelmanson JE, Jäger AK, van Staden J. Zulu medicinal plants with antibacterial activity. J Ethnopharmacol2000. Mar;69(3):241-246 10.1016/S03788741(99)00147-6 [PubMed] [Cross Ref]

26. Stulberg DL, Penrod MA, Blatny RA. Common bacterial skin infections. Am Fam Physician 2002. Jul;66(1):119124 [PubMed]

27. Kluytmans J, van Belkum A, Verbrugh $H$. Nasal carriage of Staphylococcus aureus: epidemiology, underlying mechanisms, and associated risks. Clin Microbiol Rev 1997. Jul;10(3):505-520 [PMC article] [PubMed]

28. I.Abulyazid, Elsayed M.E.Mahdy and Ragaa M.Ahmed, Biochemical study for the effect of henna (Lawsonia inermis) on Escherichia coli, Arabian Journal of Chemistry, Volume

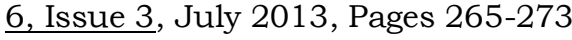


29. Syed Muhammad Ghufran Saeed, Syed Asad Sayeed, Seema Ashraf, Shahina Naz , Rahmanullah Siddiqi, Rashida Ali and M. Ahmed Mesaik, A New Method for the Isolation and Purification of Lawsone from Lawsonia Inermis and its Ros Inhibitory Activity Pak. J. Bot., 45(4): 1431-1436, 2013.

30. Elham Abdelbasit Suleiman and Elbasheir Ahmed Mohamed, In Vitro Activity of Lawsonia inermis (Henna) on Some Pathogenic Fungi, Journal of Mycology Volume 2014 (2014), Article ID 375932, 5 pages http:/ / dx.doi.org/10.1155/2014/375932

31. E. Goun, G. Cunningham, D. Chu, C. Nguyen, and D. Miles, "Antibacterial and antifungal activity of Indonesian ethnomedical plants," Fitoterapia, vol. 74, no. 6, pp. 592-596, 2003. View at $\underline{\text { Publisher }}$ View at Google Scholar . View at Scopus

32. H. S. Muhammad and S. Muhammad, "The use of Lawsonia inermis linn. (henna) in the management of burn wound infections," African Journal of Biotechnology, vol. 4, no. 9, pp. 934-937, 2005. View at Google Scholar . View at Scopus

33. K. N. Jallad and C. Espada-Jallad, "Lead exposure from the use of Lawsonia inermis (Henna) in temporary paint-ontattooing and hair dying," Science of the Total Environment, vol. 397, no. 1-3, pp.
244-250, 2008. View at Publisher - View at Google Scholar $\cdot$ View at Scopus

34. M. A. Abdulmoneim, "Evaluation of Lawsonia inermis Linn. (Sudanese Henna) leaf extract as an antimicrobial agent," Research Journal of Biological Sciences, vol. 2, pp. 417-423, 2007. View at Google Scholar

35. N. A. A. Ali, W.-D. Jülich, C. Kusnick, and U. Lindequist, "Screening of Yemeni medicinal plants for antibacterial and cytotoxic activities," Journal of Ethnopharmacology, vol. 74, no. 2, pp. 173179, 2001. View at Publisher . View at Google Scholar View at Scopus

36. R. D. Tripathi, H. S. Srivastava, and S. N. Dixit, "A fungitoxic principle from the leaves of Lawsonia inermis Lam," Experientia, vol. 34, no. 1, pp. 51-52, 1978. View at Publisher . View at Google Scholar View at Scopus

37. Chowdhury Mobaswar Hossain, Himangshu Sekhar Maji and Pranabesh Chakraborty, Hepatoprotective Activity of Lawsonia Inermis Linn, Warm Aqueous Extract in Carbon Tetrachloride Induced Hepatic Injury in Wister Rats, Asian Journal of Pharmaceutical and Clinical Research Vol. 4, Issue 3, 2011 ISSN - 0974-2441

38. Emin Zumrutdal and Mehmet Ozaslan, A Miracle Plant for the Herbal Pharmacy; Henna (Lawsonia inermis). International Journal of Pharmacology, 8: 483-489, 2012. 